\title{
НЕЙРОНАЛЬНА МОЛЕКУЛА КЛІТИННОЇ АДГЕЗІЇ І ПОКАЗНИКИ ОКИСНОГО СТРЕСУ В СЕРЦІ ЩУРІВ ЗА УМОВ ЕКСПЕРИМЕНТАЛЬНОЇ ГІПЕРГЛІКЕМІЇ ТА ВПЛИВУ МЕЛАТОНІНУ
}

Вступ. На сьогодні відомо, що цукровий діабет викликає серйозні патологічні зміни мікроциркуляторного русла в багатьох органах і тканинах та водночас пов'язаний з підвищеним ризиком розвитку коронарних і перифреричних макросудинних патологій. Окисний стрес, що виникає в тканинах організму за умов хронічної гіперглікемії, та послаблення антиоксидантної активності є пусковим механізмом розвитку діабетичних ускладнень. Фізіологічна активність міокарда залежить від регуляції ЦНС.

Мета дослідження - вивчити зміни вмісту нейрональної молекули клітинної адгезії і показників окисного стресу в серці щурів за умов гіперглікемії та впливу мелатоніну.

Методи дослідження. Дослідження проводили на статевозрілих щурах-самцях лінії Вістар. Тварин поділили на 3 групи (n=7): 1-ша - контрольна; 2-га - щури з індукованим чукровим діабетом 2 типу; 3-тя тварини, які отримали мелатонін після індукції цукрового діабету 2 типу. Рівень загального протеїну визначали за методом Бредфорда, вміст малонового діальдегіду - фоотометрично за реакцією з тіобарбітуровою кислотою, активність супероксиддисмутази - за реакцією окиснення кверцетину, вміст нейрональної молекули клітинної адгезії-згідно з імуноферментним аналізом. Статистичну оцінку даних виконано за однофакторним дисперсійним аналізом ANOVA.

Результати й обговорення. Встановлено зміни вмісту нейрональної молекули клітинної адгезії та показників окисного стресу в серці щурів за умов гіперглікемії. Вміст мембранної фрорми цієї молекули в серці тварин з індукованим цукровим діабетом 2 типу мав вірогідну тенденцію до збільшення. Відзначено достовірне підвищення вмісту малонового діальдегіду, а також значне зниження активності супероксиддисмутази і каталази в серці щурів діабетичної групи, що є характерною ознакою окисного стресу. Застосування мелатоніну після індукції цукрового діабету 2 типу призводило до зменшення вмісту нейрональної молекули клітинної адгезії в серці піддослідних тварин порівняно з групою щурів з індукованим цукровим діабетом 2 типу.

Висновки. Окисний стрес спричиняє метаболічні порушення в тканинах міокарда, що призводить до появи і розвитку діабетичних ускладнень. Нейрональна молекула клітинної адгезії може відігравати роль компенсаторного кардіопротекторного фрактора, що активується за умов метаболічного стресу. Встановлено позитивний ефект мелатоніну в рамках захисту метаболізму мембранних адгезивних протеїнів у серці щурів при гіперглікемії.

КЛЮЧОВІ СЛОВА: нейрональна молекула клітинної адгезії; окисний стрес; серце; гіперглікемія; щури.

ВСТУП. Цукровий діабет є всесвітньою проблемою охорони здоров'я, яка зараз уражає понад 200 мільйонів людей у всьому світі. Порушення синтезу інсуліну та стійка гіперглікемія - основні причини розвитку цукрового діабету. Однак приблизно 90 \% усіх хворих на цукровий діабет мають діабет 2 типу [1]. Гіперглікемія є одним із поширених етіологічних фракторів індукції внутрішніх захворювань, у тому числі порушення фрункціонування центральної нервової системи та іннервації важливих органів [2]. На сьогодні відомо, що цукровий діабет викликає серйозні (с Ю. П. Ковальчук, Г. Ю. Павленко, С. В. Кириченко, В. І. Жилюк, Г. О. Ушакова, 2021. патологічні зміни мікроциркуляторного русла в багатьох органах і тканинах та водночас пов'язаний з підвищеним ризиком розвитку коронарних і периферичних макросудинних патологій [3]. Поширеність цукрового діабету 2 типу збільшується одночасно $з$ віком та підвищує ризик виникнення серцево-судинних захворювань у 2-3 рази $[4,5]$.

Окисний стрес, що виникає в тканинах організму за умов хронічної гіперглікемії, та послаблення антиоксидантної активності є пусковим механізмом розвитку діабетичних ускладнень [6]. Результати численних досліджень показали 
значний терапевтичний ефект приймання антиоксидантів при експериментальному цукровому діабеті [7]. Мелатонін (N-ацетил-5-метокситриптамін) є циркадною ендокринною молекулою, яка секретується шишкоподібною залозою та виконує важливі фрункції, такі, як регуляція біоритму та захисна антиоксидантна реакція. Як було показано в попередніх дослідженнях, мелатонін - високоефективний антиоксидант, що може запобігти ушкодженню клітин міокарда за умов цукрового діабету [8]. Також мелатонін і його похідні мають протекторний ефект на клітинні мембрани, електронотранспортний ланцюг та мітохондріальну ДНК при окисному стресі [9]. Встановлено, що ін'єкції мелатоніну запобігають ускладненням діабетичної ішемії/реперфузії міокарда, це, можливо, забезпечується за рахунок збереження мітохондріальної активності шляхом посилення активності супероксиддисмутази (СОД), комплексів окисного фоссрорилювання (II, III і IV) та утворення АТФ, що гальмує утворення продуктів пероксидного окиснення ліпідів і $\mathrm{H}_{2} \mathrm{O}_{2}$ у мітохондріях та процеси апоптозу в міокарді [10].

Фізіологічна активність міокарда залежить від регуляції центральної нервової системи. Головним регулятором розвитку та виживання нейронів, міграції і проростання нейритів за фрізіологічних умов та при метаболічному стресі $€$ нейрональна молекула клітинної адгезії (НМКА) [11].

Нейрональні молекули клітинної адгезії $€$ протеїнами, зміна вмісту яких суттєво впливає на нейрональну та синаптичну пластичність, вони належать до великої надродини імуноглобулінів, більшість представників якої беруть участь в організації міжклітинних контактів адгезивного типу [12]. За своєю хімічною природою НМКА $€$ глікопротеїнами, що забезпечують гомофрільну комунікацію між клітинами. Більшість НМКА - трансмембранні протеїни, які лише один раз перетинають плазматичну мембрану; внутрішньоклітинні домени мають різні розміри та, як вважають, беруть участь у зв'язуванні зі цитоскелетом або в клітинній передачі сигналу [13]. Одна з форм НМКА не перетинає плазматичної мембрани та прикріплюється до неї за рахунок глікозилфосфратидилінозитолу, який "заякорює" цю фрорму в мембрані. Інша фрорма НМКА - секреторна, може включатись у позаклітинний матрикс. Порушення фрункцій НМКА зумовлює руйнування нервових відростків, а також гальмування росту відростків нервових клітин, які прикріплюються один до одного $з$ утворенням пучків [14]. Нейрональна молекула клітинної адгезії синтезується, головним чином, на поверхні нервових клітин, у меншій кількості - на гліо- цитах головного мозку та периферичної нервової системи, найменше їх визначається у скелетних м'язах, активованих Т-лімфоцитах, нульових або NK-лімфоцитах і клітинах нейроендокринної тканини. Експресія НМКА регіонально регулюється в серці. Характер експресії узгоджується з гіпотезою про те, що даний глікопротеїн бере участь у дисреренціюванні стінок передсердь і шлуночків, злитті міжпередсердної перегородки з ендокардіальними подушками, злитті цих подушок, фрормуванні та ремоделюванні шлуночкових трабекул [15]. Нейрональна молекула клітинної адгезії не тільки забезпечує взаємодію між клітинами та позаклітинним оточенням, але значною мірою визначає швидкість пролісрерації клітин, активацію визначених генів, будову і структуру клітин [16]. Найчастіше НМКА використовують як маркер розвитку захворювань нервової системи, але сказане вище свідчить про те, що вона також $є$ актуальною мішенню для серця.

Мета дослідження - вивчити зміни вмісту нейрональної молекули клітинної адгезії і показників окисного стресу в серці щурів за умов гіперглікемії та впливу мелатоніну.

МЕТОДИ ДОСЛІДЖЕННЯ. Дослідження проводили на статевозрілих щурах-самцях лінії Вістар масою 230-250 г. Тварин поділили на 3 групи (n=7). Контрольною була 1-ша група. До 2-ї групи входили щури з індукованим цукровим діабетом 2 типу (ЦД-2), яким одноразово внутрішньочеревно вводили водний розчин нікотинаміду (Sigma-Aldrich, США) в дозі 230 мг/кг і через 15 хв після цього - стрептозотоцину (SigmaAldrich, США) в дозі 65 мг/кг у цитратному бусрері, $\mathrm{pH} 4,5$. Для досліджень використовували тварин з підвищеним рівнем глюкози - 8-14 ммоль/л. Вміст глюкози у крові визначали за допомогою глюкометра "Optium Omega" (Abbott Diabetes Care Inc., США) через 3 дні після введення стрептозотоцину та шестигодинної депривації їжі 3 вільним доступом до води. До 3-ї групи входили щури, які отримали мелатонін (Вітамелатонін, ВАТ "Київський вітамінний завод", Україна) внутрішньошлунково один раз на день протягом останніх 7 днів експерименту в дозі 10 мг/кг після індукції ЦД-2, доза препарату відповідає терапевтичному діапазону $\left(E_{50}\right)$, який рекомендують в експериментальних дослідженнях відповідно до формули перерахунку.

Дослідження проводили згідно з Положенням про використання тварин у біомедичних дослідах [17]. Наприкінці експерименту тварин декапітували під наркозом тіопентал-натрію (40 мкг/кг). 3 метою дослідження НМКА за допомогою диференційного центрифугування було 
отримано фрракції, що містили мембранні протеїни [18]. Центриоругування проводили на ультрацентрифузі К-70 при 20000 g. Вихідний бусрер містив трис- $\mathrm{HCl}-25 \mathrm{mM}(\mathrm{pH} 7,4)$, етилендіамінтетраоцет (ЕДТО) - 1 мМ, $\beta$-меркаптоетанол 2 мМ, фенілметилсульфонілфрторид (ФМСФ) $0,2 \mathrm{MM}$, азид натрію $\left(\mathrm{NaN}_{3}\right)-3$ мМ у співвідношенні 1:10 (вказані реагенти було придбано у фрірмі “Sigma”, США).

Рівень загального протеїну в отриманих фрракціях визначали за методом Бредфорда та виражали у міліграмах на 100 мг тканини [19].

Вміст малонового діальдегіду (МДА) визначали фротометрично за реакцією з тіобарбітуровою кислотою [20], активність СОД - за методом [21], активність каталази - за методом [22].

Вміст НМКА у мембранній фрракції, отриманій із серця, визначали згідно з імунофрерментним аналізом, використовуючи кролячі моноспецифрічні поліклональні антитіла проти НМКА і вторинні антикролячі анти-IgG, мічені пероксидазою (Abcam, Cambridge, Велика Британія), та високоочищену HMKA (R\&D Systems, CША, Minneapolis, Канада) як стандарт [23]. Отримані результати вимірювали за допомогою ІФА-рідера "Anthos 2010" (Фінляндія) при 492 нм. Кількість НМКА виражали в мікрограмах на 100 мг тканини.

Статистичну оцінку даних виконано з використанням пакета Microsoft Excel 2013 за однофракторним дисперсійним аналізом ANOVA. Статистично значущими вважали дані при $\mathrm{p}<0,05$.

РЕЗУЛЬТАТИ Й ОБГОВОРЕННЯ. У ХОДі екСперименту на першому етапі досліджено загальну кількість протеїнів. Показники загальної кількості мембранних протеїнів, які екстраговано із серця щурів контрольної групи, встановлено

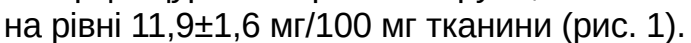

За умов експериментального ЦД-2 встановлено достовірне збільшення загальної кількості

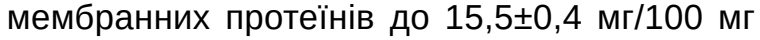
тканини порівняно 3 показником тварин контрольної групи. При застосуванні мелатоніну в дозі 10 мг/кг після індукції ЦД-2 протягом 7 днів достовірних змін загальної кількості мембранних протеїнів порівняно з групою ЦД-2 не зазначено і встановлено на рівні 16,0 0,4 мг/100 мг тканини.

Вміст мембранної форми НМКА в серці щурів 3 індукованим цукровим діабетом 2 типу мав достовірну тенденцію до збільшення 8,6 60,2 мкг/100 мг тканини порівняно з контроль-

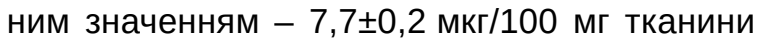
$(p<0,05)$ (рис. 2).

Застосування мелатоніну після індукції ЦД-2 протягом 7 днів показало достовірне зменшення вмісту НМКА в серці піддослідних тварин порівняно 3 групою щурів 3 індукованим цукровим діабетом 2 типу, та встановлено на рівні $6,9 \pm 0,3$ мкг/100 мг тканини. Нейрональна молекула клітинної адгезії - кардіопротекторний фрактор, що активується при метаболічному стресі в кардіоміоцитах та $€$ головним регулятором розвитку і виживання нейронів. Результати імуногістохімічних аналізів на моделі інсраркту міокарда в миші показали, що вміст НМКА збільшувався в залишкових серцевих міоцитах у ділянці інораркту. Підвищену експресію НМКА також було виявлено під час періоду ремоделювання на моделі серцевої недостатності, спричиненої гіпертензією, в щурів [11].

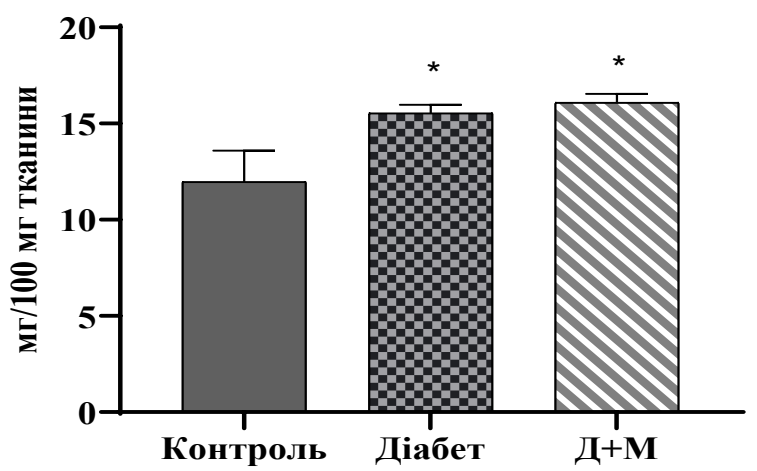

Рис. 1. Загальний вміст протеїнів у мембранних фрракціях, які отримано із серця щурів.

Примітки:

1. $\mathrm{n}=6$.

2. * - достовірність відмінностей $р<0,05$ порівняно 3 Контролем.

3. Контроль - контрольна група тварин; Діабет - щури з індукованим цукровим діабетом 2 типу; Д+М - тварини, які отримали мелатонін у дозі 10 мг/кг після індукції ЦД-2 протягом 7 днів.

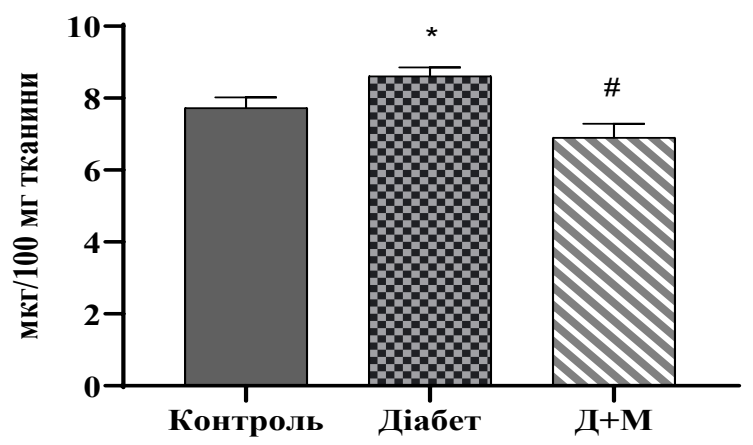

Рис. 2. Вміст нейрональної молекули клітинної адгезії в серці щурів.

Примітки:

1. $\mathrm{n}=6$.

2. * - достовірність відмінностей $р<0,05$ порівняно 3 Контролем; " - достовірність відмінностей $р<0,05$ порівняно з Діабетом.

3. Контроль - контрольна група тварин; Діабет - щури 3 індукованим цукровим діабетом 2 типу; Д+М - тварини, які отримали мелатонін у дозі 10 мг/кг після індукції ЦД-2 протягом 7 днів. 
Результати дослідження вмісту продуктів пероксидного окиснення ліпідів у тканинах серця показали достовірне збільшення вмісту МДА у тварин діабетичної групи на 20 \% порівняно 3 контрольною групою (рис. 3, А). Підвищення рівня продуктів пероксидного окиснення ліпідів $€$ характерною ознакою окисного стресу і призводить до посиленого утворення активних форм кисню, що, у свою чергу, спричиняє ушкодження клітинних мембран та погіршення патологічних процесів у тканинах [24]. Ін'єкції мелатоніну сприяли значному зменшенню вмісту МДА в тканинах міокарда.

У здоровому організмі активні фрорми кисню $€$ типовими продуктами обмінних процесів, і їх утилізацію забезпечують такі ензими антиоксидантного захисту, як супероксиддисмутаза, каталаза, глутатіонредуктаза та ін. [25]. При розвитку окисного стресу, спричиненого хронічною гіперглікемією, активність цих ензимів значно знижується, що супроводжується збільшенням вмісту активних фоорм кисню [26]. За умов експериментального ЦД-2 активність СОД була знижена на 40 \% порівняно з контрольною групою (рис. 3, Б). Терапія мелатоніном сприяла достовірному підвищенню активності СОД у тканинах серця.

Активність каталази також була значно знижена в щурів після індукції ЦД-2 протягом 7 днів (рис. 3, В). Водночас ін'єкції мелатоніну сприяли відновленню цих показників до рівня контрольної групи, що підтвердилося результатами попередніх досліджень [8]. X. Wang та ін. припускали, що каталаза катаболізує $\mathrm{H}_{2} \mathrm{O}_{2}$, зменшуючи накопичення АФК, чим може знизити ушкодження тканин міокарда при діабеті за рахунок часткового зниження автофрагії [27].

Таким чином, терапія мелатоніном протидіяла розвитку окисного стресу, який виникав у тканинах міокарда внаслідок хронічної гіперглікемії, що запобігало структурно-срункціональним порушенням у клітинах.

Діабет 2 типу пов'язаний із хронічною підтримкою гіперглікемії, що призводить до окисного стресу, пов'язаного з високим рівнем глюкози. Це впливає на порушення стабільності мембрани кардіоміоцитів і, відповідно як наслідок, може впливати на функціонування клітин та роботу серця загалом.

У наших дослідженнях показано, що на тлі загального підвищення рівня мембранних протеїнів спостерігають також збільшення вмісту нейрональної молекули клітинної адгезії, що $€$ одним із ключових регуляторів міжклітинної комунікації кардіоміоцитів за рахунок формування адгезивних контактів, тим самим впливаючи на загальні функції серця. Таким чином, зберігаєть- ся енантіостаз за рахунок посилення іннервації. Мелатонін має антиоксидантні властивості, що підтверджується результатами попередніх досліджень [28]. Він також відіграє важливу роль у захисті клітинних мембран від пероксидного
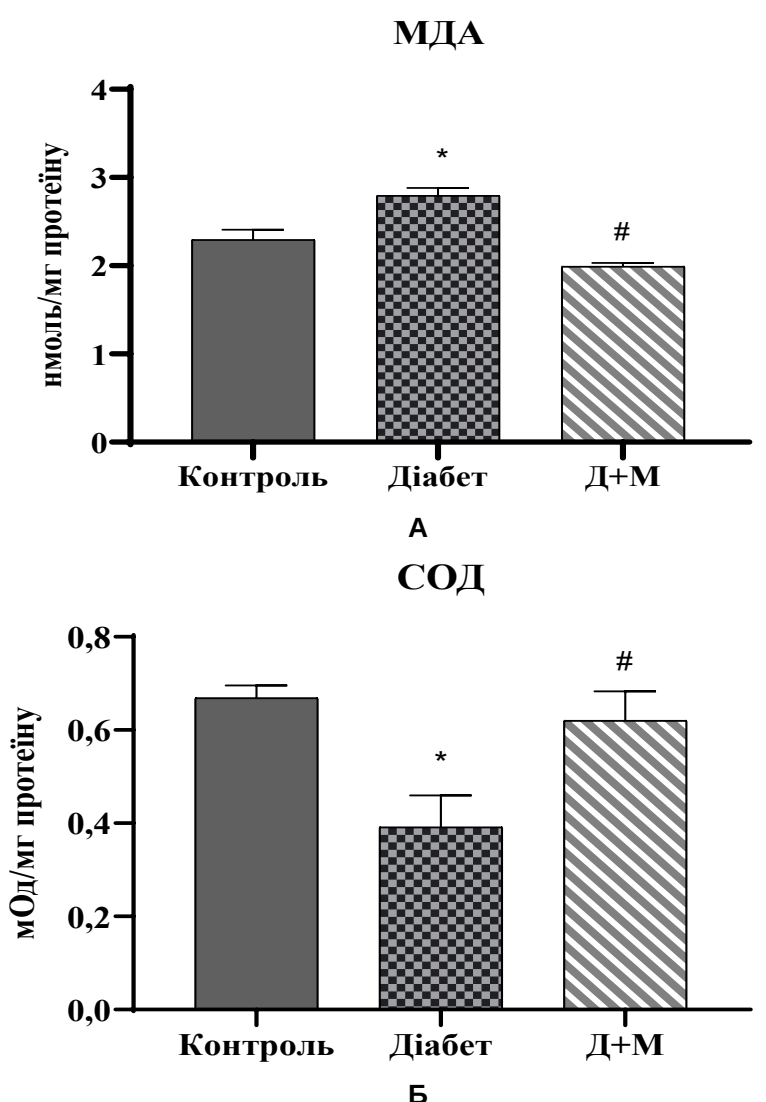

Каталаза

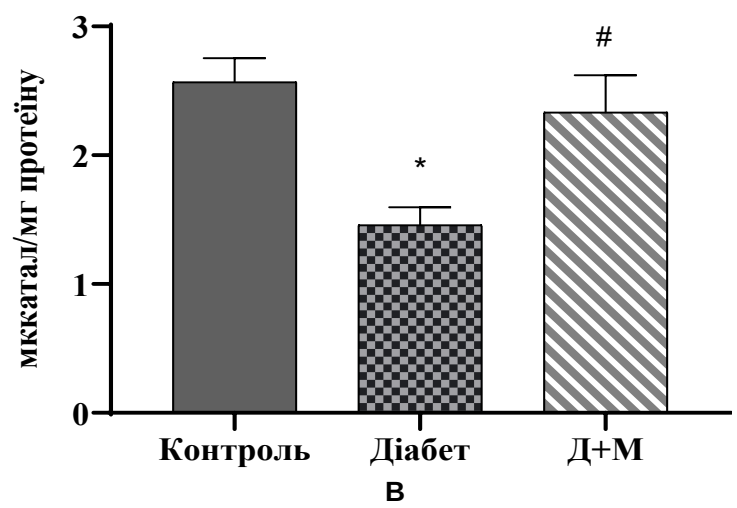

Рис. 3. Вміст малонового діальдегіду та ензимів антиоксидантного захисту в тканинах міокарда щурів.

Примітки:

1. $n=6$.

2. МДА - малоновий діальдегід (А), СОД - супероксиддисмутаза (Б), каталаза (В).

3. * - достовірність відмінностей $р<0,05$ порівняно 3 Контролем; " - достовірність відмінностей р<0,05 порівняно з Діабетом

4. Контроль - контрольна група тварин; Діабет - щури з індукованим цукровим діабетом 2 типу; Д+М - тварини, які отримали мелатонін у дозі 10 мг/кг після індукції ЦД-2 протягом 7 днів. 
окиснення ліпідів [9]. Частина його ефективності in vivo може бути пов'язана з каскадом продукуючих метаболітів мелатонінових антиоксидантів. На відміну від більшості низькомолекулярних біологічних антиоксидантів, таких, як вітамін С (аскорбінова кислота), $\alpha$-токофрерол (вітамін Е), ліпоєва кислота і т. д., мелатонін не піддається окисно-відновному циклу. Він діє як прямий поглинач вільних радикалів зі здатністю виводити токсини як з реактивного кисню, так і з активних форм кисню, а також за рахунок підвищення активності систем антиоксидантного захисту.
ВИСНОВКИ. Окисний стрес, який виникає за умов хронічної гіперглікемії, спричиняє метаболічні порушення в тканинах міокарда, що призводить до появи і розвитку діабетичних ускладнень. Нейрональна молекула клітинної адгезії може відігравати роль компенсаторного кардіопротекторного фрактора, що активується при метаболічному стресі. Отримані дані вказують на позитивний есект мелатоніну в рамках захисту метаболізму мембранних адгезивних протеїнів у серці щурів за умов гіперглікемії.

\section{СПИСОК ЛІТЕРАТУРИ}

1. Henning R. J. Type-2 diabetes mellitus and cardiovascular disease / R. J. Henning // Future Cardiol. 2018. - 14, No. 6. - P. 491-509. -Access mode : https:// pubmed.ncbi.nlm.nih.gov/30409037/.

2. Effects of diabetes mellitus on astrocyte GFAP and glutamate transporters in the CNS / E. Coleman, R. Judd, L. Hoe [et al.] // Glia. - 2004. - 48, No. 2. P. 166-178. - Access mode : https://onlinelibrary.wiley. com/doi/abs/10.1002/glia.20068.

3. Angiogenic abnormalities in diabetes mellitus: mechanistic and clinical aspects / G. P. Fadini, M. Albiero, B. M. Bonora, A. Avogaro // J. Clin. Endocrinol. Metab. 2019. - 104, No. 11. - P. 5431-5444. - Access mode : https://pubmed.ncbi.nlm.nih.gov/31211371/.

4. Momeni M. New advances in perioperative cardioprotection / M. Momeni, S. De Hert // F1000Res., 8:F1000 Faculty Rev-538. - 2019. - Access mode : https://doi.org/10.12688/f1000research.17184.1.

5 . Efficacy and safety of ezetimibe in combination with atorvastatin for acute coronary syndrome patients accompanied with type 2 diabetes: A single-center, nonrandomized cohort study / Z. Huang, Q. Li, W. Ye, Q. Zhang, X. Li // Chem. Pharm. Bull (Tokyo). - 2019. 67, No. 5. - P. 419-425. - Access mode : https://pubmed. ncbi.nIm.nih.gov/31061366/.

6. Samarghandian S. Catechin treatment ameliorates diabetes and its complications in streptozotocin-induced diabetic rats / S. Samarghandian, M. Azimi-Nezhad, T. Farkhondeh // Dose Response. - 2017. - 15, No. 1. 1559325817691158. eCollection Jan-Mar 2017. - Access mode : https://pubmed.ncbi.nlm.nih.gov/28228702/.

7. Maritim A. C. Diabetes, oxidative stress, and antioxidants: a review / A. C. Maritim, R. A. Sanders, J. B. Watkins // J. Biochem. Mol. Toxicol. - 2003. - 17, No. 1. - P. 24-38. - Access mode : https://onlinelibrary. wiley.com/doi/abs/10.1002/jbt.10058.

8. Kandemir Y. B. Melatonin protects against streptozotocin-induced diabetic cardiomyopathy through the mammalian target of rapamycin (mTOR) signaling pathway / Y. B. Kandemir, V. Tosun, Ü. Güntekin // Adv. Clin. Exp. Med. - 2019. - 28, No. 9. - P. 1171-1177. Access mode: https://pubmed.ncbi.nlm.nih.gov/30843672/.
9. Protective effects of melatonin and mitochondriatargeted antioxidants against oxidative stress: a review / M. R. Ramis, S. Esteban, A. Miralles [et al.] // Curr. Med. Chem. - 2015. - 22, No. 22. - P. 2690-2711. - Access mode : https://pubmed.ncbi.nlm.nih.gov/26087763/.

10. Melatonin ameliorates myocardial ischemia/ reperfusion injury in type 1 diabetic rats by preserving mitochondrial function: role of AMPK-PGC-1a-SIRT3 signaling / L. Yu, B. Gong, W. Duan [et al.] // Sci. Rep. 2017. - 7. - P. 41337. - Access mode : https://www.nature.com/articles/srep41337.

11. NCAM mimetic peptides: Potential therapeutic target for neurological disorders / C. Chengyan, G. Yue, L. Xiaoyan [et al.] // Neurochem. Res. - 2018. - 43, No. 9. - P. 1714-1722. - Access mode : https://pubmed. ncbi.nlm.nih.gov/30003388/.

12. Neural cell adhesion molecule is a cardioprotective factor up-regulated by metabolic stress / K. Nagao, K. Ono, Y. Iwanaga [et al.] // J. Mol Cell Cardiol. - 2010. 48, No. 6. - P. 1157-1168. - Access mode : https:// pubmed.ncbi.nlm.nih.gov/19853610/.

13. Sheng L. Neural cell adhesion molecule 2 promotes the formation of filopodia and neurite branching by inducing submembrane increases in Ca2+ levels I L. Sheng, I. Leshchyns'ka, V. Sytnyk // J. Neurosci. 2015. - 35, No. 4. - P. 1739-1752. - Access mode : https://www.jneurosci.org/content/35/4/1739/tab-articleinfo.

14. Sytnyk V. N. Distribution of cell adhesion molecules on the surface of branching neurites: Modelinherited effects of branch diametr and mode of transport / V. N. Sytnyk, A. E. Dityatev, S. M. Korogod // Neurophysiology. - 2001. - 33, No. 1. - P. 11-14. - Access mode : https://link.springer.com/article/10.1023/A:1010451928251.

15. Myocardial expression level of neural cell adhesion molecule correlates with reduced left ventricular function in human cardiomyopathy / N. Kazuya, S. Naoya, I. Katsumi [et al.] // Circ. Heart Fail. - 2014. - 7, No. 2. P. 351-358. - Access mode : https://pubmed.ncbi.nlm. nih.gov/24365773/.

16. Exenatide alters gene expression of neural cell adhesion molecule (NCAM), intercellular cell adhesion 
molecule (ICAM), and vascular cell adhesion molecule (VCAM) in the hippocampus of type 2 diabetic model mice / E. Gumuslu, N. Cine, M. E. Gökbayrak [et al.] // Med. Sci. Monit. - 2016. - No. 22. - P. 2664-2669. Access mode : https://pubmed.ncbi.nlm.nih.gov/ 274652471

17. Етика лікаря та права людини: положення про використання тварин у біомедичних дослідах // Експерим. та клініч. фрізіологія та біохімія. - 2003. № 2 (22). - C. 108-109.

18. Фоменко О. 3. Протеїни астроглії у мозку щурів в умовах експериментального хронічного гепатиту та дії 2-оксоглутарату [Електронний ресурс] / О. 3. Фоменко, Г. О. Ушакова, С. Г. Пієржиновський // Укр. біохім. журн. - 2011. - 83, № 1. - С. 69-76. Режим доступу : http://nbuv.gov.ua/UJRN/BioChem 2011_83_1_10.

19. Bradford M.M. A rapid and sensitive method for the quantitation of microgram quantities of protein utilizing the principle of protein-dye binding / M. M. Bradford // Anal. Biochem. - 1976. - 72. - P. 248-254. - Access mode : https://experiments.springernature.com/articles/10.1007/978-1-59745-198-7_4.

20. Андреева Л. Ю. Модифрикация метода определения перекисного окисления липидов в тесте с тиобарбитуровой кислотой / Л. Ю. Андреева, Л. А. Кожемякин, А. А. Кышкун // Лаб. дело. - 1988. - № 11. C. $41-43$.

21. Костюк В. А. Простой и чувствительный метод определения активности супероксиддисмутазы, основанный на реакции окисления кверцетина [Электронный ресурс] / В. А. Костюк, А. И. Потапович, Ж. В. Ковалева // Вопросы мед. химии. - 1990. - 36, № 2. - С. 88-91. Режим доступа : http://pbmc.ibmc. msk.ru/ru/article-ru/PBMC-1990-36-2-88/.

\section{REFERENCES}

1. Henning, R.J. (2018). Type-2 diabetes mellitus and cardiovascular disease. Future Cardiol., 14 (6), 491509. Retrieved from: https://pubmed.ncbi.nlm.nih. gov/30409037/.

2. Coleman, E., Judd, R, Hoe, L, Dennis, J \& Posner P. (2004). Effects of diabetes mellitus on astrocyte GFAP and glutamate transporters in the CNS. Glia, 48 (2), 166178. Retrieved from: https://onlinelibrary.wiley.com/doi/ abs/10.1002/glia.20068.

3. Fadini, G.P., Albiero, M., Bonora, B.M. \& Avogaro, A. (2019). Angiogenic abnormalities in diabetes mellitus: mechanistic and clinical aspects. J. Clin. Endocrinol. Metab., 104 (11), 5431-5444. Retrieved from: https://pubmed.ncbi.nlm.nih.gov/31211371/.

4. Momeni, M. \& De Hert, S. (2019). New advances in perioperative cardioprotection. F1000Res., 8:F1000 Faculty Rev-538. Retrieved from: https://doi.org/10.12688/ f1000research.17184.1.

5. Huang, Z., Li, Q., Ye, W., Zhang, Q. \& Li, X. (2019). Efficacy and safety of ezetimibe in combination with atorvastatin for aacute coronary syndrome patients accompanied with type 2 diabetes: A single-center, non-
22. Метод определения активности каталазы / М. А. Королюк, Л. К. Иванова, И. Г. Майорова, В. А. Токарева // Лаб. дело. - 1988. - № 4. - С. 44-47.

23. Нго Т. Т. Иммуноферментный анализ / Т. Т. Нго, Г. М. Ленхофрф, А. Яклич. - М. : Мир, 1998. - 444 с.

24. Inhibition of liver mitochondrial membrane permeability transition pore opening by quercetin and vitamin $E$ in streptozotocin-induced diabetic rats / O. O. Daniel, A. O. Adeoye, J. Ojowu, O. O. Olorunsogo // Biochemical and Biophysical Research Communications. 2018. - 504, No. 2. -P. 460-469. - Access mode : https:// pubmed.ncbi.nlm.nih.gov/30195498/.

25. Influence of apocynin on cardiac remodeling in rats with streptozotocin-induced diabetes mellitus / R. Gimenes, C. Gimenes, C. M. Rosa [et al.] // Cardiovasc. Diabetol. - 2018. - 17, No. 1. - P. 15. - Access mode : https://cardiab.biomedcentral.com/articles/10.1186/ s12933-017-0657-9.

26. Melatonin therapy for diabetic cardiomyopathy: a mechanism involving Syk-mitochondrial complex I-SERCA pathway / H. Zhou, Y. Yue, J. Wang [et al.] // Cell Signal. - 2018. - No. 47. - P. 88-100. - Access mode : https://www.sciencedirect.com/science/article/ abs/pii/S0898656818300767.

27. Catalase ameliorates diabetes-induced cardiac injury through reduced p65/RelA-mediated transcription of BECN1 / X. Wang, Y. Tao, Y. Huang [et al.] // J. Cell Mol. Med. -2017. -21, No. 12. -P. 3420-3434. -Access mode : https://pubmed.ncbi.nlm.nih.gov/28643395/.

28. Muñoz H., Contribution to determining the antioxidant capacity of melatonin in orodispersible tablets - comparison with reference antioxidants I H. Muñoz, S. García, A. Ruiz // Arch. Med. Sci. - 2020. 16, No. 4. - P. 871-877. - Access mode : https://pubmed. ncbi.nlm.nih.gov/32542090/.

randomized cohort study. Chem. Pharm. Bull. (Tokyo), 67 (5), 419-425. Retrieved from: https://pubmed.ncbi.nlm. nih.gov/31061366/.

6. Samarghandian, S., Azimi-Nezhad, M. \& Farkhondeh, T. (2017). Catechin treatment ameliorates diabetes and its complications in streptozotocin-induced diabetic rats. Dose Response, 15 (1), 1559325817691158. Retrieved from: https://pubmed.ncbi.nlm.nih.gov/28228702/.

7. Maritim, A.C., Sanders, R.A. \& Watkins, J.B. (2003). Diabetes, oxidative stress, and antioxidants: a review. J. Biochem. Mol. Toxicol., 17 (1), 24-38. Retrieved from: https://onlinelibrary.wiley.com/doi/abs/10.1002/ jbt.10058.

8. Kandemir, Y.B., Tosun, V. \& Güntekin, Ü. (2019). Melatonin protects against streptozotocin-induced diabetic cardiomyopathy through the mammalian target of rapamycin (mTOR) signaling pathway. Adv. Clin. Exp. Med., 28 (9), 1171-1177. Retrieved from: https://pubmed. ncbi.nlm.nih.gov/30843672/.

9. Ramis, M.R., Esteban, S., Miralles, A., Dun-Xian, T. \& Reiter, R.J. (2015). Protective effects of melatonin and mitochondria-targeted antioxidants against oxidative 
stress: a review. Curr. Med. Chem., 22 (22), 2690-2711. Retrieved from: https://pubmed.ncbi.nlm.nih.gov/26087763/.

10. Yu, L., Gong, B., Duan, W., Fan, C., Zhang, J. \& $\mathrm{Li}$, Z. et al. (2017). Melatonin ameliorates myocardial ischemia/reperfusion injury in type 1 diabetic rats by preserving mitochondrial function: role of AMPK-PGC1a-SIRT3 signaling. Sci Rep, 7, 41337. Retrieved from: https://www.nature.com/articles/srep41337.

11. Chengyan, C., Yue, G., Xiaoyan, L., Aline, T., Shen, L. (2018). NCAM Mimetic peptides: Potential therapeutic target for neurological disorders. Neurochem. Res., 43 (9), 1714-1722. Retrieved from: https://pubmed. ncbi.nlm.nih.gov/30003388/.

12. Nagao, K., Ono, K., Iwanaga, Y., Tamaki, Y., Kojima, Y. \& Horie, T. et al. (2010). Neural cell adhesion molecule is a cardioprotective factor up-regulated by metabolic stress. J. Mol. Cell Cardiol., 48 (6), 1157-1168. Retrieved from: https://pubmed.ncbi.nlm.nih.gov/ 19853610/.

13. Sheng, L., Leshchyn'ka, I. \& Sytnyk, V. (2015). Neural cell adhesion molecule 2 promotes the formation of filopodia and neurite branching by inducing submembrane increases in Ca2+ levels. J. Neurosci., 35 (4), 1739-1752. Retrieved from: https://www.jneurosci.org/ content/35/4/1739/tab-article-info.

14. Sytnyk, V.N., Dityatev, A.E. \& Korogod, S.M. (2001). Distribution of cell adhesion molecules on the surface of branching neurites: Model-inherited effects of branch diametr and mode of transport. Neurophysiology, 33 (1), 11-14. Retrieved from: https://link.springer.com/ article/10.1023/A:1010451928251.

15. Kazuya, N., Naoya, S., Katsumi, I., Motoko, T., Kohei, F. \& Koji, U. et al. (2014). Myocardial expression level of neural cell adhesion molecule correlates with reduced left ventricular function in human cardiomyopathy. Circ. Heart Fail, 7 (2), 351-358. Retrieved from: https:// pubmed.ncbi.nlm.nih.gov/24365773/.

16. Gumuslu, E., Cine, N., Gökbayrak, M. E., Mutlu, O., Komsuoglu, Celikyurt I. \& Ulak, G. (2016). Exenatide alters gene expression of neural cell adhesion molecule (NCAM), intercellular cell adhesion molecule (ICAM), and vascular cell adhesion molecule (VCAM) in the hippocampus of type 2 diabetic model mice. Med. Sci. Monit., 22, 2664-2669. Retrieved from: https:// pubmed.ncbi.nlm.nih.gov/27465247/.

17. (2003). Etyka likaria ta prava liudyny: polozhennia pro vykorystannia tvaryn u biomedychnykh doslidakh [Medical ethics and human rights: provisions on the use of animals in biomedical experiments]. Ekperym. ta klin. fiziolohiia ta biokhimiia - Experimental and Clinical Physiology and Biochemistry, 22 (2), 108-109 [in Ukrainian].

18. Fomenko, O.Z., Ushakova, G.O., \& Piyerzhynovskyy, S.H. (2011). Proteiny astrohlii u mozku shchuriv $v$ umovakh eksperymentalnoho khronichnoho hepatytu ta dii 2-oksohlutaratu [Astroglia proteins in rat brain under experimental chronic hepatitis and 2-oxoglutarate]. Ukr. biokhim. zhurn. - Ukrainian Biochemical J., 83 (1), 69-75. Retrieved from: http://nbuv.gov.ua/UJRN/BioChem_ 2011_83_1_10. [in Ukrainian].
19. Bradford, M.M. (1985). A rapid and sensitive method for the quantitation of microgram quantities of protein utilizing the principle of protein-dye binding. Anal. Biochem., 72, 248-254. Retrieved from: https://experiments.springernature.com/articles/10.1007/978-159745-198-7_4.

20. Andreyeva, L.Y., Kozhemyakin, L.A., \& Kyshkun, A.A. (1988). Modifikatsiya metoda opredeleniya perekisnogo okisleniya lipidov $v$ teste $s$ tiobarbiturovoy kislotoy [Modification of the method for determining lipid peroxidation in the test with thiobarbituric acid]. Laboratornoye delo - Laboratory Work, 11, 41-43 [in Russian].

21. Kostyuk, V.A., Potapovich, A.I., \& Kovaleva, Zh.V. (1990). Prostoy i chuvstvitelnyy metod opredeleniya aktivnosti superoksiddismutazy, osnovannyy na reaktsii okisleniya kvertsetina [A simple and sensitive method for determining the activity of superoxide dismutase, based on the oxidation reaction of quercetin]. Voprosy meditsinskoy khimii - Medicinal Chemistry Issues, 36 (2), 88-91. Retrieved from: http://pbmc.ibmc.msk.ru/ru/articleru/PBMC-1990-36-2-88/. [in Russian].

22. Korolyuk, M.A., Ivanova, L.K., Mayorova, I.G., \& Tokareva, V.A. (1988). Metod opredeleniya aktivnosti katalazy [Method for determination of catalase activity]. Laboratornoye delo - Laboratory Work, 4, 44-47 [in Russian].

23. Ngo, T.T., Lenkhoff, G.M., Yaklich, A. (1998). Immunofermentnyy analiz [Linked immunosorbent assay]. Moscow: Mir [in Russian].

24. Daniel, O.O., Adeoye, A.O., Ojowu, J., \& Olorunsogo, O.O. (2018). Inhibition of liver mitochondrial membrane permeability transition pore opening by quercetin and vitamin $E$ in streptozotocin-induced diabetic rats. Biochemical and Biophysical Research Communications, 504 (2), 460-469. Retrieved from https:// pubmed.ncbi.nlm.nih.gov/30195498/.

25. Gimenes, R., Gimenes, C., Rosa, C.M., Xavier, N.P., Campos, D.H. \& Fernandes, A.A. et al. (2018). Influence of apocynin on cardiac remodeling in rats with streptozotocin-induced diabetes mellitus. Cardiovasc Diabetol, 17 (1), 15. Retrieved from: https:// cardiab.biomedcentral.com/articles/10.1186/s12933-0170657-9.

26. Zhou, H., Yue, Y., Wang, J., Ma, Q., \& Chen, Y. (2018). Melatonin therapy for diabetic cardiomyopathy: a mechanism involving Syk-mitochondrial complex ISERCA pathway. Cell Signal, 47, 88-100. Retrieved from: https://www.sciencedirect.com/science/article/abs/pii/ S0898656818300767.

27. Wang, X., Tao, Y., Huang, Y., Zhan, K., Xue, M. \& Wang, Y. et al. (2017). Catalase ameliorates diabetesinduced cardiac injury through reduced p65/RelA-mediated transcription of BECN1. J. Cell Mol. Med., 21 (12), 3420-3434. Retrieved from: https://pubmed.ncbi.nlm.nih. gov/28643395/.

28. Muñoz, H., García, S. \& Ruiz, A. (2020). Contribution to determining the antioxidant capacity of melatonin in orodispersible tablets - comparison with reference antioxidants. Arch. Med. Sci., 16 (4), 871-877. Retrieved from: https://pubmed.ncbi.nlm.nih.gov/32542090/. 
Ю. П. Ковальчук ${ }^{1}$, Г. Ю. Павленко ${ }^{1}$, С. В. Кириченко ${ }^{1}$ В. И. Жилюк ${ }^{2}$, Г. А. Ушакова ${ }^{1}$ ДНЕПРОВСКИЙ НАЦИОНАЛЬНЫЙ УНИВЕРСИТЕТ ИМЕНИ ОЛЕСЯ ГОНЧАРА ДНЕПРОВСКИЙ ГОСУДАРСТВЕННЫЙ МЕДИЦИНСКИЙ УНИВЕРСИТЕТ

\title{
НЕЙРОНАЛЬНАЯ МОЛЕКУЛА КЛЕТОЧНОЙ АДГЕЗИИ И ПОКАЗАТЕЛИ ОКИСЛИТЕЛЬНОГО СТРЕССА В СЕРДЦЕ КРЫС ПРИ ЭКСПЕРИМЕНТАЛЬНОЙ ГИПЕРГЛИКЕМИИ И ВЛИЯНИИ МЕЛАТОНИНА
}

\begin{abstract}
Резюме
Вступление. На сегодня известно, что сахарный диабет вызывает серьезные патологические изменения микроциркуляторного русла во многих органах и тканях и одновременно связан с повышенным риском развития коронарных и периферических макрососудистых патологий. Окислительный стресс, возникающий в тканях организма в условиях хронической гипергликемии, и ослабление антиоксидантной активности являются пусковым механизмом развития диабетических осложнений. Физиологическая активность миокарда зависит от регуляции ЦНС.

Цель исследования - изучить изменения содержания нейрональной молекулы клеточной адгезии и показателей окислительного стресса в сердце крыс в условиях гипергликемии и влияния мелатонина.

Методы исследования. Исследования проводили на половозрелых крысах-самцах линии Вистар. Животных разделили на 3 группы (n=7): 1-я - контрольная; 2-я - крысы с индуцированным сахарным диабетом 2 типа; 3-я-животные, получившие мелатонин после индукции сахарного диабета 2 типа. Уровень общего протеина определяли по методу Брэдфрорда, содержание малонового диальдегида - фотометрически по реакции с тиобарбитуровой кислотой, активность супероксиддисмутазы - по реакции окисления кверцетина, содержание нейрональной молекулы клеточной адгезии - согласно иммуноферментному анализу. Статистическую оценку данных выполнено по однофракторному дисперсионному анализу ANOVA.

Результаты и обсуждение. Установлено изменения содержания нейрональной молекулы клеточной адгезии и показателей окислительного стресса в сердце крыс в условиях гипергликемии. Содержание мембранной фрормы этой молекулы в сердце животных с индуцированным сахарным диабетом 2 типа имело достоверную тенденцию к увеличению. Отмечено достоверное повышение содержания малонового диальдегида, а также значительное снижение активности супероксиддисмутазы и каталазы в сердце крыс диабетической группы, что является характерным признаком окислительного стресса. Применение мелатонина после индукции сахарного диабета 2 типа приводило к уменьшению содержания нейрональной молекулы клеточной адгезии в сердче подопытных животных по сравнению с группой крыс с индуцированным сахарным диабетом 2 типа.

Выводы. Окислительный стресс является причиной метаболических нарушений в тканях миокарда, что приводит к появлению и развитию диабетических осложнений. Нейрональная молекула клеточной адгезии может играть роль компенсаторного кардиопротекторного фактора, который активируется в условиях метаболического стресса. Установлено положительный эффектт мелатонина в рамках защиты метаболизма мембранных адгезивных протеинов в сердце крыс при гипергликемии.
\end{abstract}

КЛЮЧЕВЫЕ СЛОВА: нейрональная молекула клеточной адгезии; окислительный стресс; сердце; гипергликемия; крысы.

Y. P. Kovalchuk' , G. Yu. Pavlenko' ${ }^{1}$, S. V. Kyrychenko ${ }^{1}$, V. I. Zhyliuk², G. O. Ushakova ${ }^{1}$ OLES HONCHAR DNIPRO NATIONAL UNIVERSITY ${ }^{1}$ DNIPRO STATE MEDICAL UNIVERSITY²

\section{NEURONAL CELL ADHESION MOLECULES AND INDICATORS OF OXIDATIVE STRESS IN THE HEART OF RATS WITH HYPERGLYCEMIA AND MELATONIN IMPACT}

\section{Summary}

Introduction. Today, it is known that diabetes causes serious pathological changes in the microcirculatory tract in many organs and tissues and at the same time is associated with an increased risk of coronary and peripheral macrovascular pathologies. Oxidative stress, which occurs in body tissues under conditions of chronic hyperglyce- 
mia, and the weakening of antioxidant activity is the trigger for the development of diabetic complications. Physiological activity of the myocardium depends on the regulation of the CNS.

The aim of the study - to investigate the change in the content of the neuronal molecule of cell adhesion and oxidative stress in the heart of rats under conditions of hyperglycemia and exposure to melatonin.

Research Methods. The study was performed on adult male Wistar rats. Animals were divided into 3 groups $(n=7): 1$ - control; 2 - animals with induced type 2 diabetes mellitus; 3 - animals that received melatonin after induction of diabetes mellitus type 2. The level of total protein was determined due to Bradford. The content of malonic dialdehyde was determined photometrically by reaction with thiobarbituric acid. Superoxide dismutase activity was determined by the oxidation reaction of quercetin. The content of NCAM was determined according to enzyme-linked immunosorbent assay. Statistical evaluation of the data was performed by one-way analysis of variance ANOVA.

Results and Discussion. Changes in the content of the neuronal cell adhesion molecule (NCAM) and markers of oxidative stress in the heart of rats under hyperglycemia were found. The content of the membrane form of the neuronal cell adhesion molecule in the heart of rats with induced type 2 diabetes had statistically supported tendency to increase. At the same time, there was a significant increase of the MDA content, as well as a decrease of the activity of superoxide dismutase and catalase in the heart of rats with type 2 diabetes, which is a characteristic feature of oxidative stress. The application of melatonin after induction of type 2 diabetes resulted in a decrease in the content of NCAM in the heart of experimental rats, compared with animals with induced type 2 diabetes.

Conclusions. Oxidative stress is the cause of metabolic disorders in myocardial tissues, which leads to the appearance and development of diabetic complications. NMCA can act as a compensatory cardioprotective factor that is activated under metabolic stress. A positive effect of melatonin in the protection of membrane adhesive protein metabolism in the heart of rats under conditions of hyperglycemia.

KEY WORDS: neural cell adhesion molecule; oxidative stress; heart; hyperglycemia; rats.

Отримано 09.02.21

Адреса для листування: Ю. П. Ковальчук, Дніпровський національний університет імені Олеся Гончара, просп. Гагаріна, 72 , Дніпро, 49010, Україна, e-mail: yulka.5868152@ukr.net. 